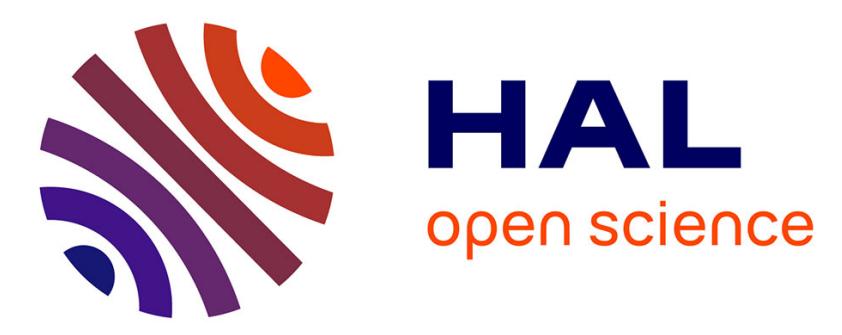

\title{
Multilingualism, Multimodality and Identity \\ Construction on French-Based Amazigh (Berber) Websites
}

Mena B. Lafkioui

\section{- To cite this version:}

Mena B. Lafkioui. Multilingualism, Multimodality and Identity Construction on French-Based Amazigh (Berber) Websites. Revue Française de Linguistique Appliquée, 2013, XVIII (2), pp.135-151. hal-01486737

\section{HAL Id: hal-01486737 \\ https://hal.science/hal-01486737}

Submitted on 6 Nov 2018

HAL is a multi-disciplinary open access archive for the deposit and dissemination of scientific research documents, whether they are published or not. The documents may come from teaching and research institutions in France or abroad, or from public or private research centers.
L'archive ouverte pluridisciplinaire HAL, est destinée au dépôt et à la diffusion de documents scientifiques de niveau recherche, publiés ou non, émanant des établissements d'enseignement et de recherche français ou étrangers, des laboratoires publics ou privés. 

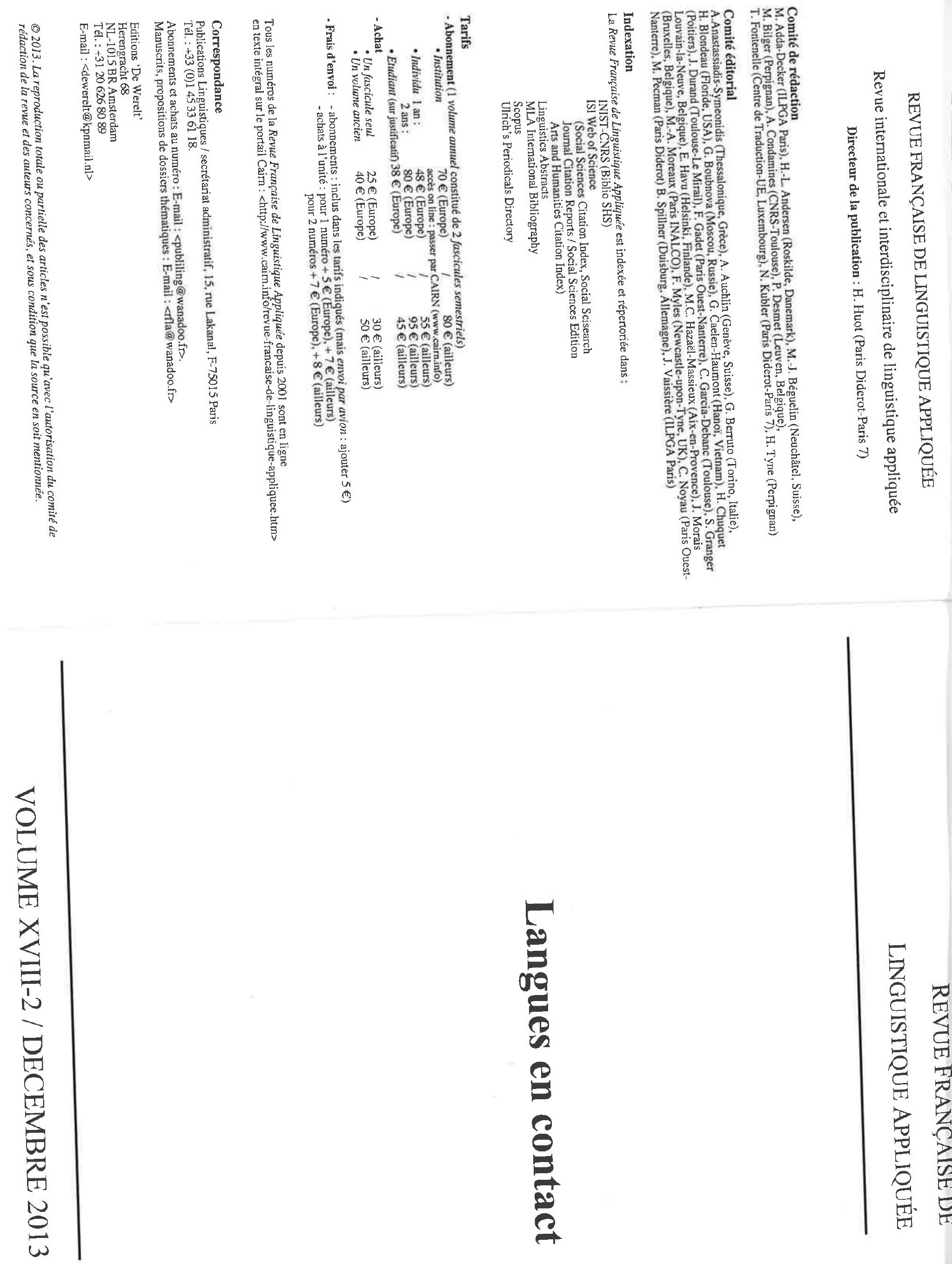


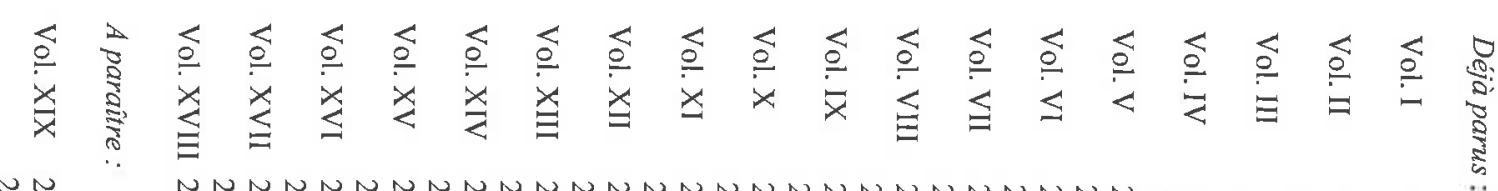

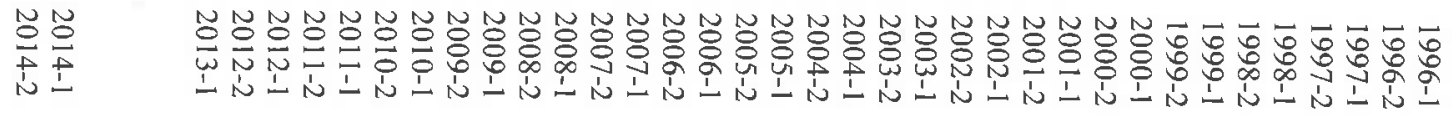

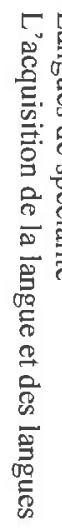

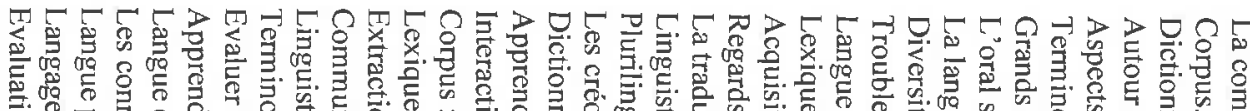

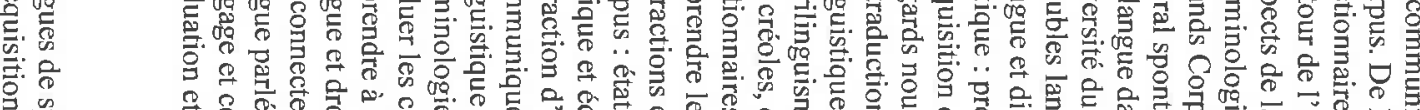

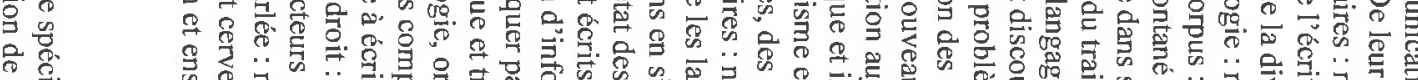

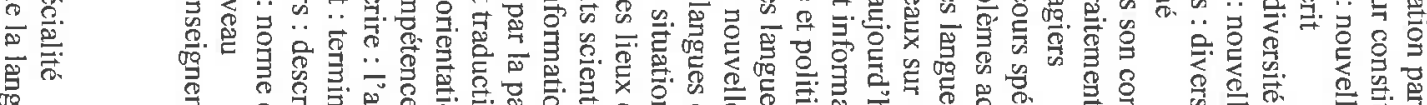

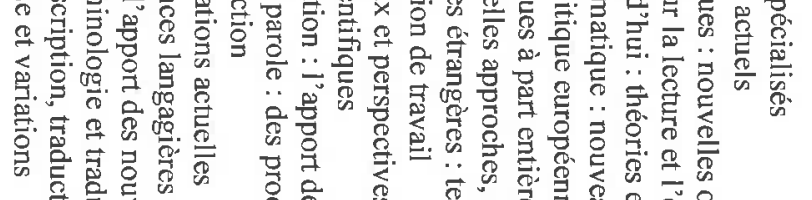

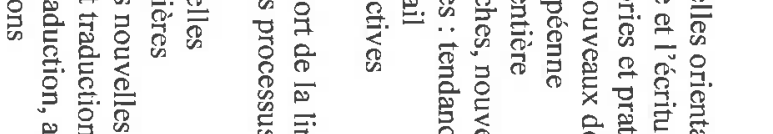

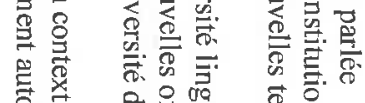

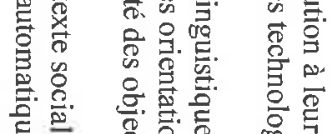

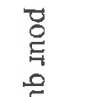

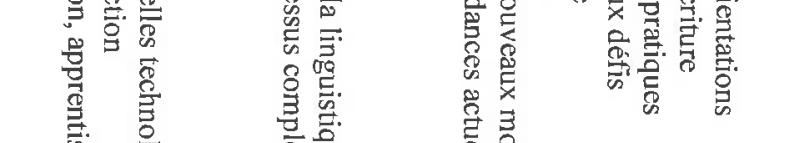

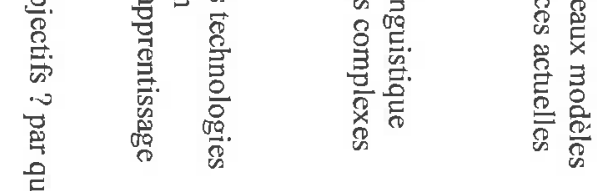

总

宽

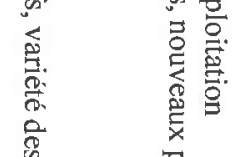

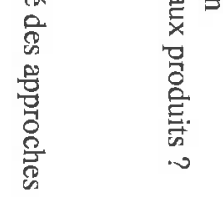

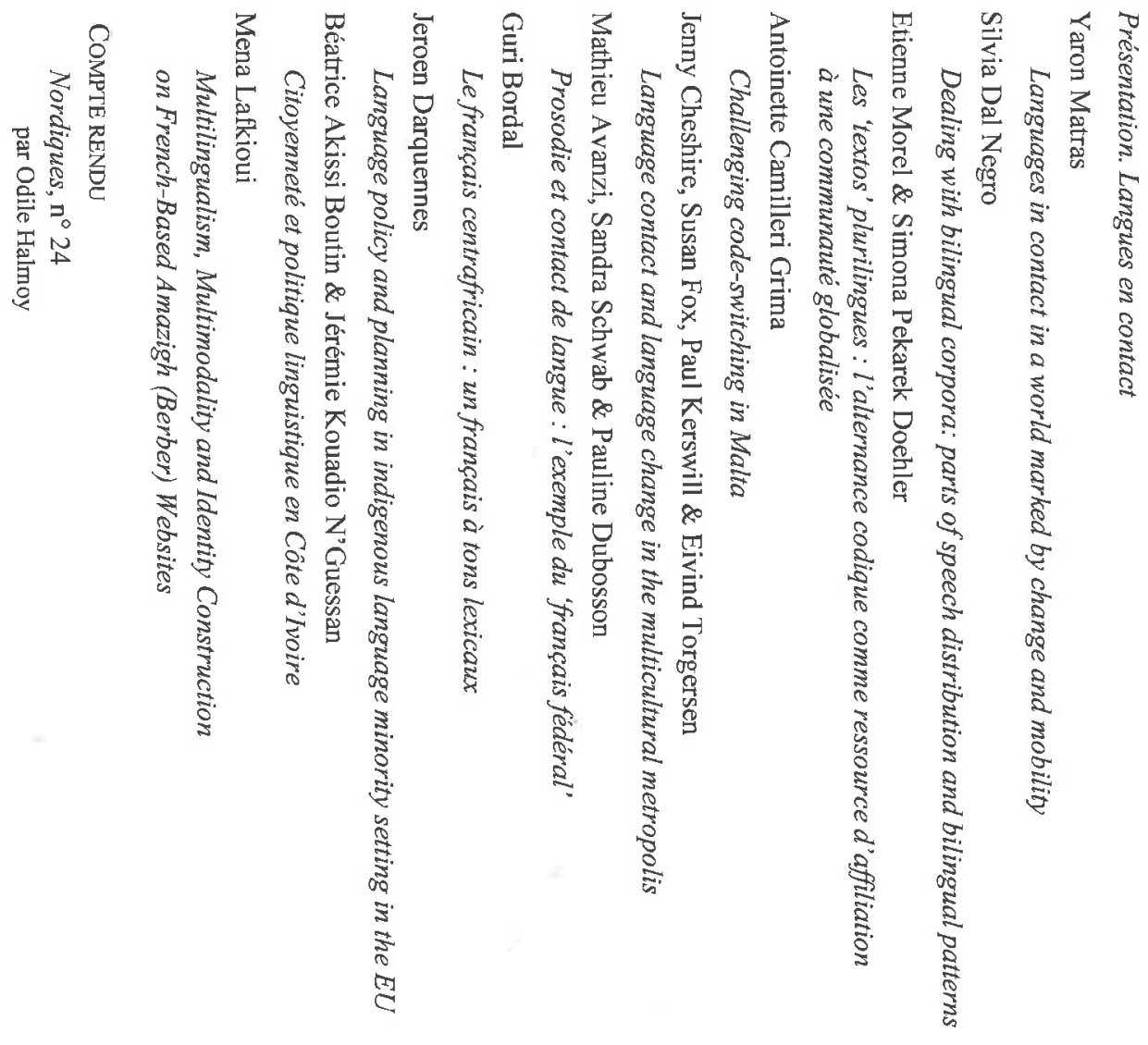

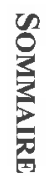

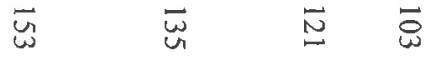

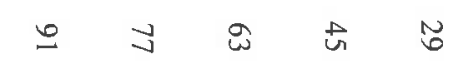




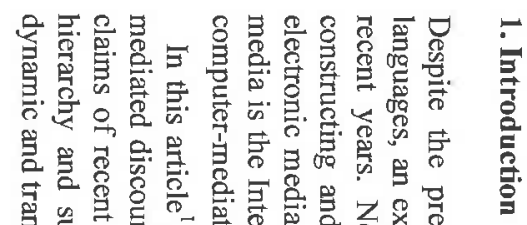

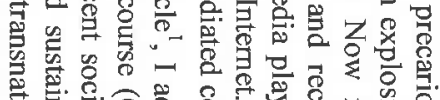

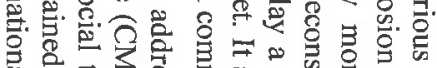

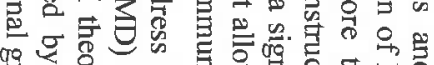

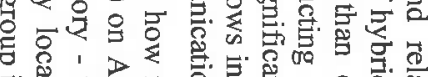

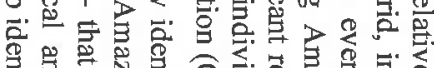

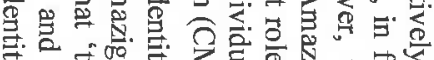

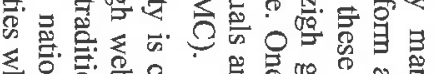

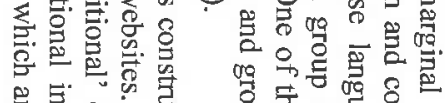

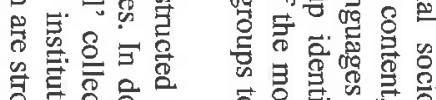

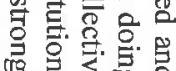

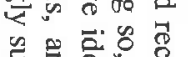

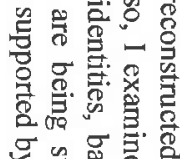
एँ

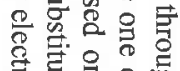

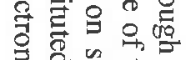

ㄱ. 을. $\overline{6}$

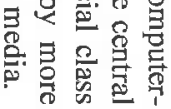
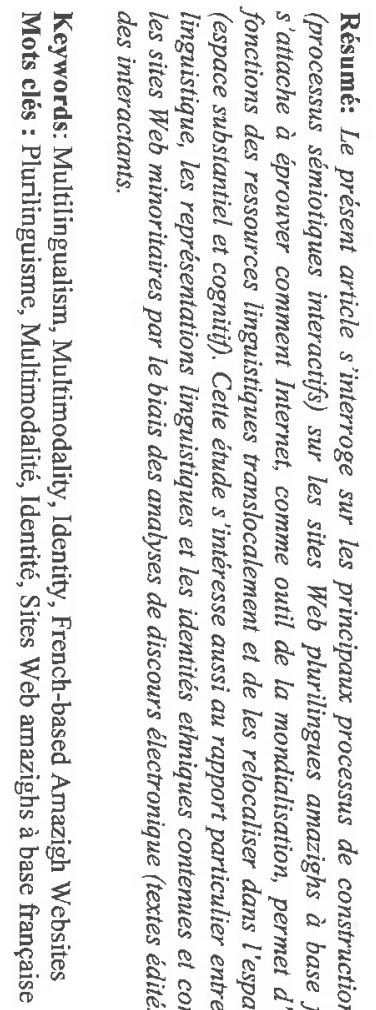

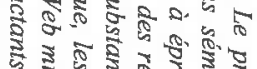

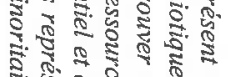

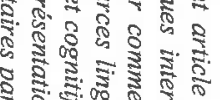

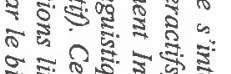

₹.

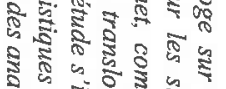

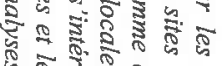

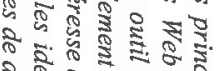

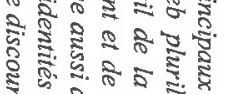

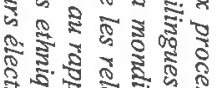

औ.

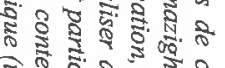

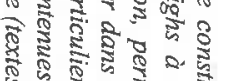

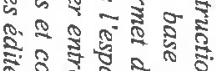

(3)

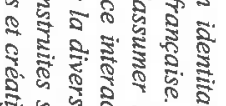

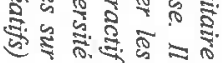

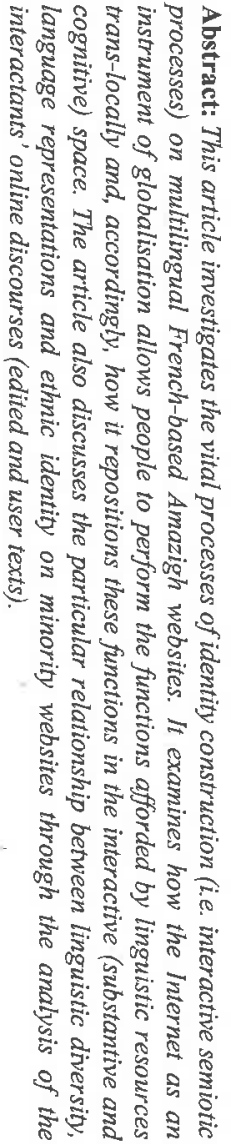




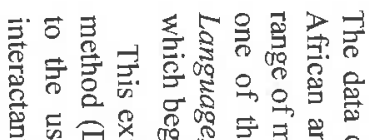

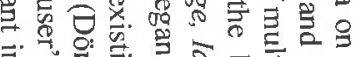

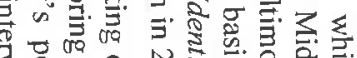

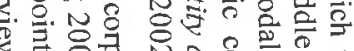

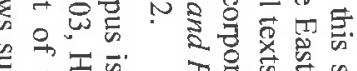

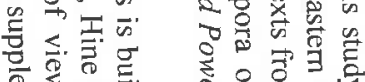
证 । के

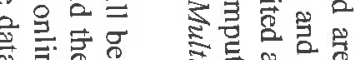

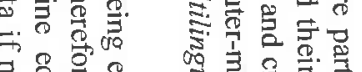

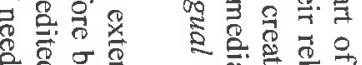
응 중 के के

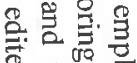
के

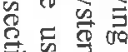

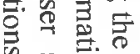

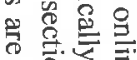

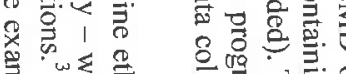

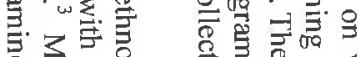

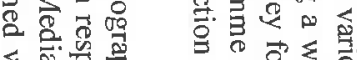

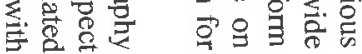
政要

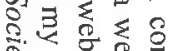

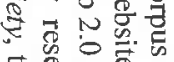
F 은 훙

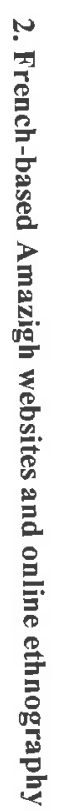

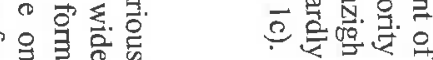

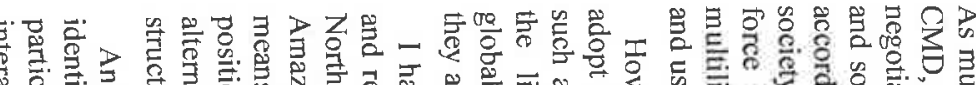

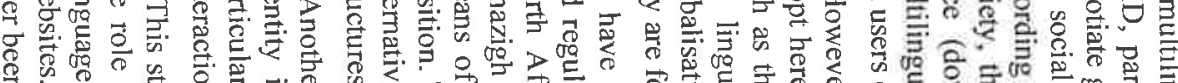

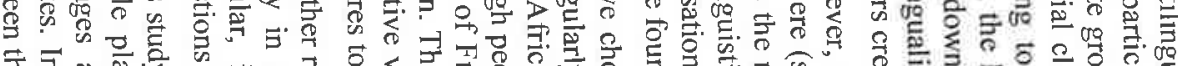

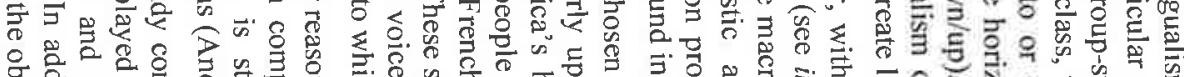

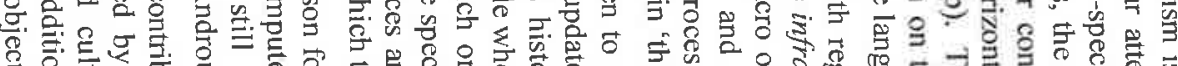

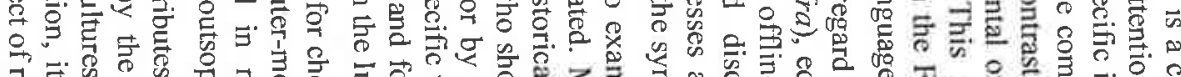

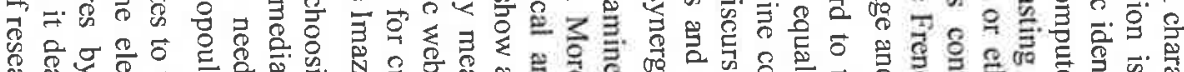

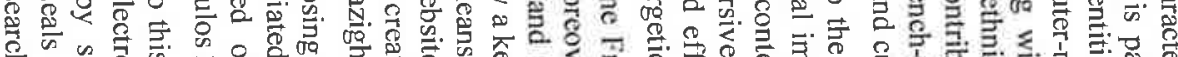

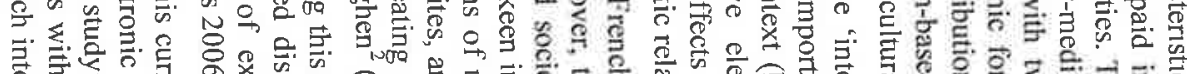

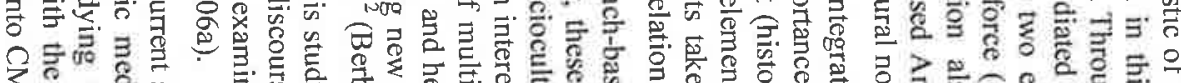

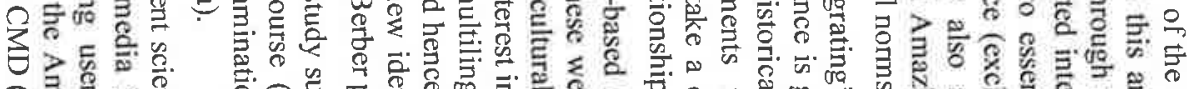

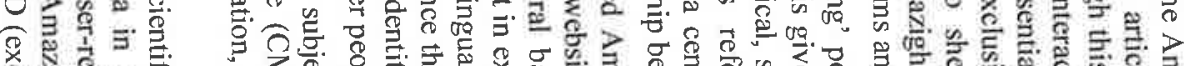

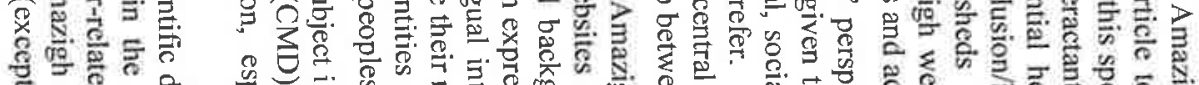
过

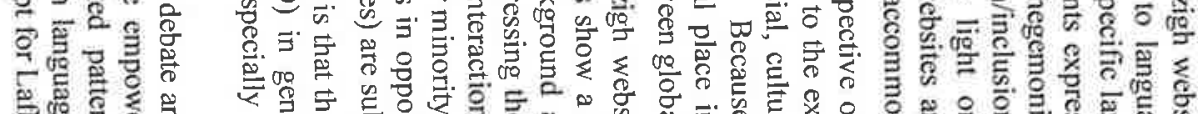

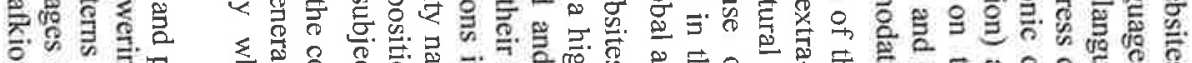

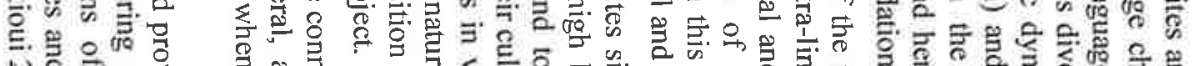

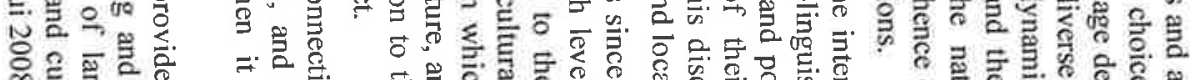

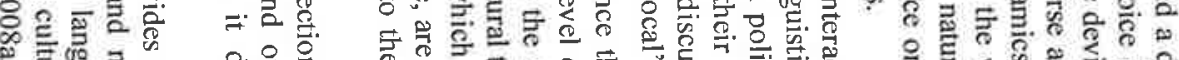

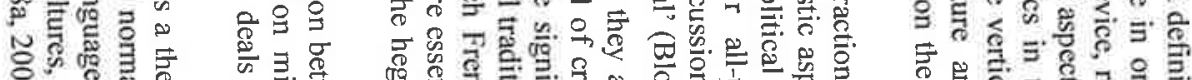

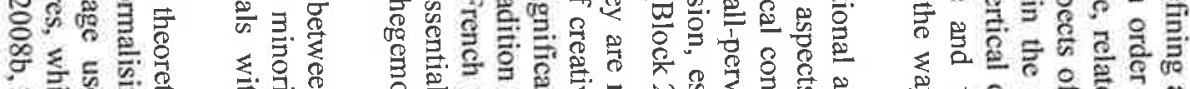

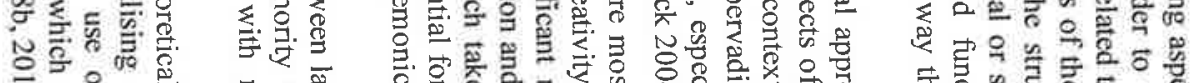

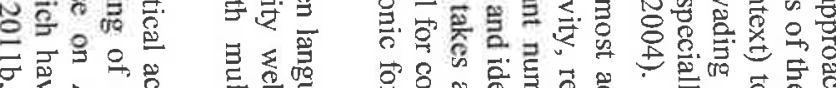

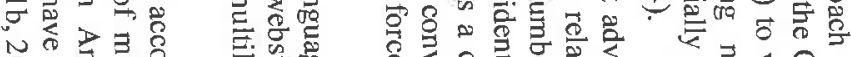

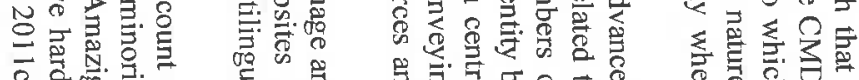

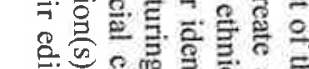

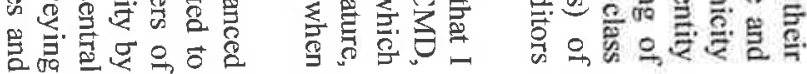

\section{ery}

W

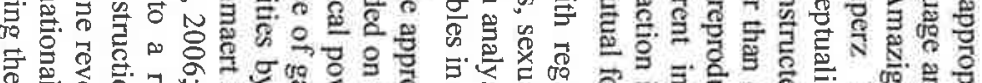

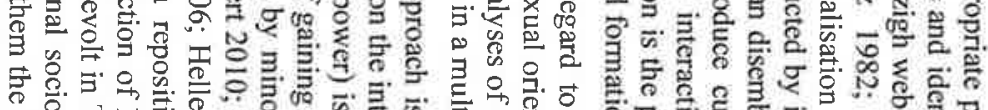

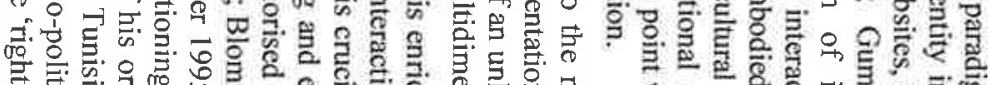
Mn tong

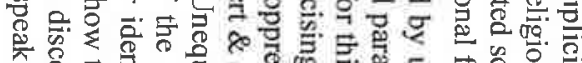
Min ${ }^{\prime}$

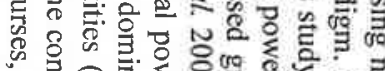
(1)

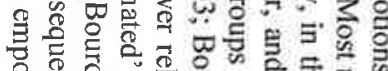

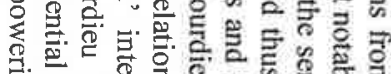
When (1) 政,

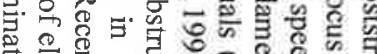

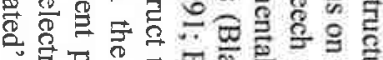

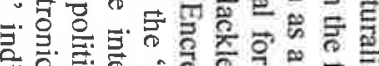
等

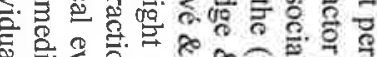

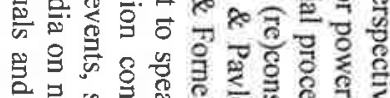

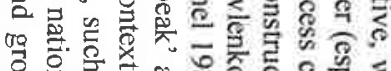

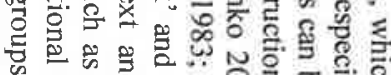

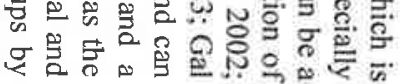

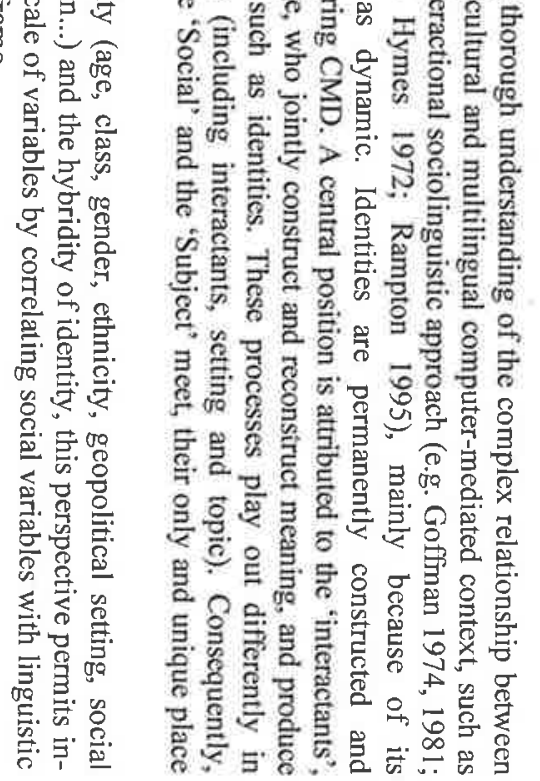

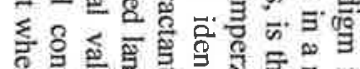

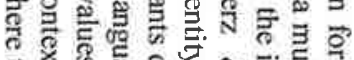

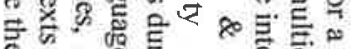

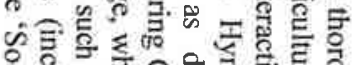

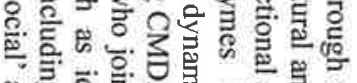
can

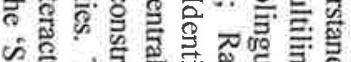

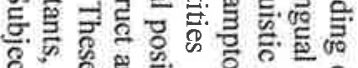
5.

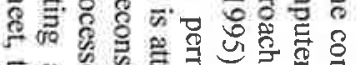

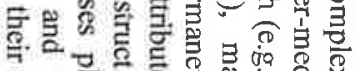

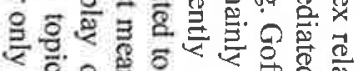

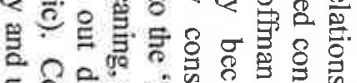

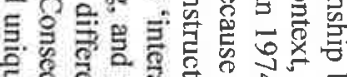

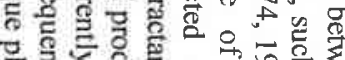

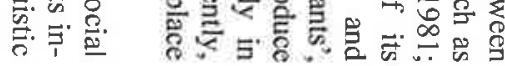

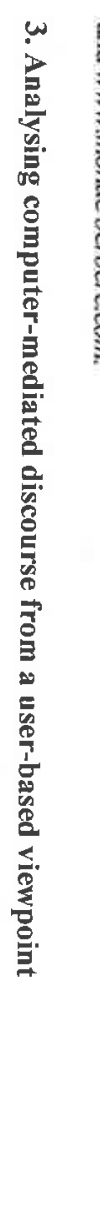




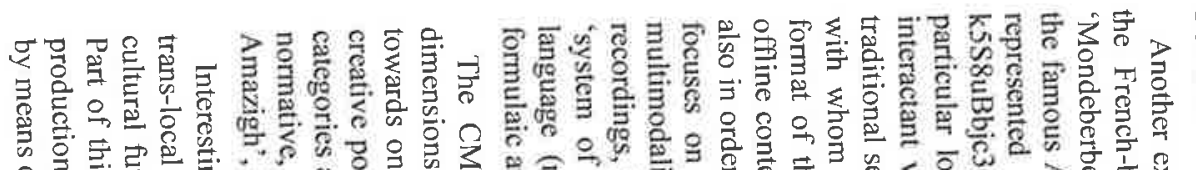

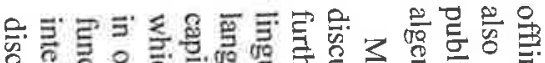

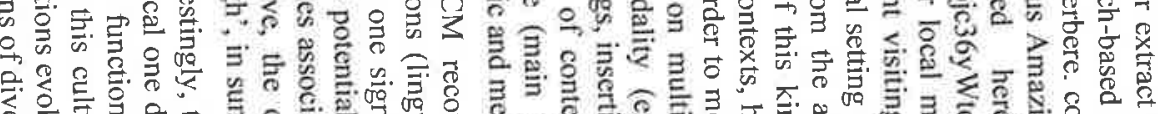

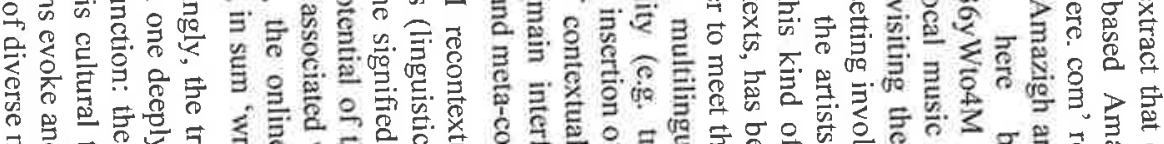

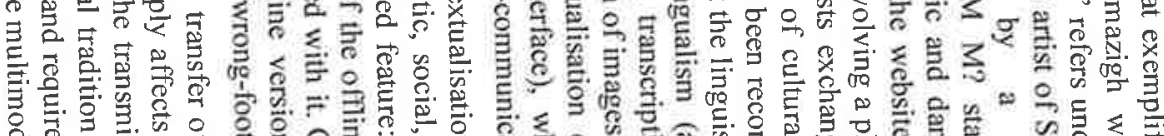

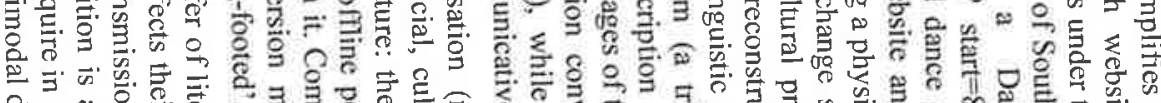

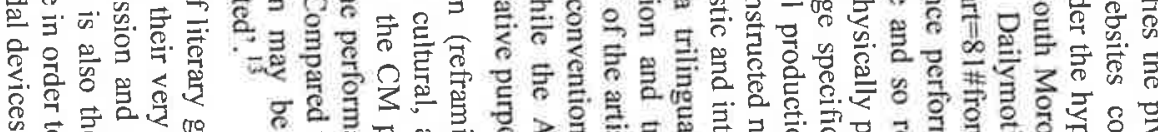

우

들

9 훙ㅁㅇㅇㅛ

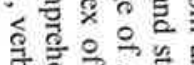

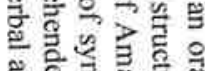

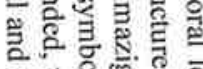

क.

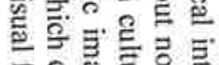

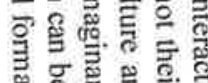

क्षै के 馬总 8

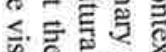
产 ॠ

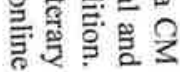

б ฉ.

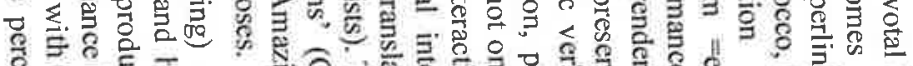

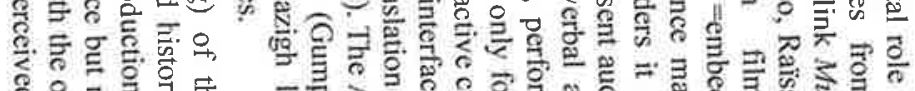

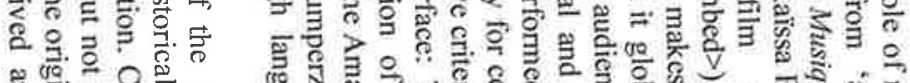

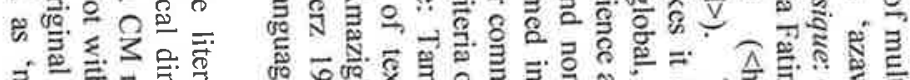

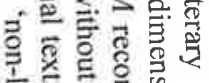

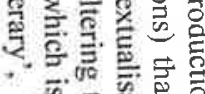

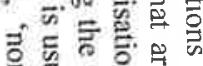
宩航

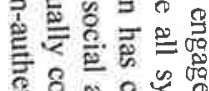

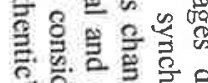

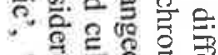

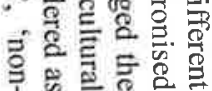

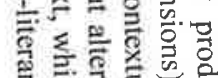

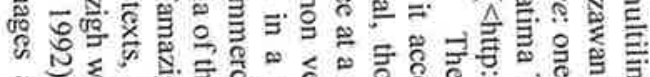
ڤ.

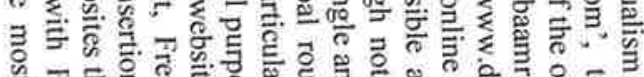

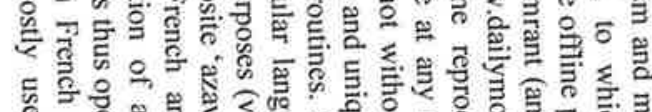
ఓ๘

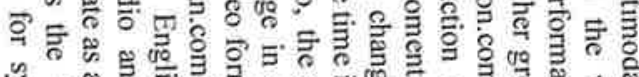

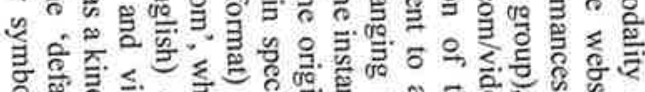

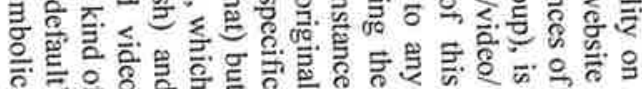

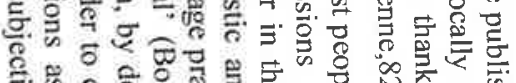

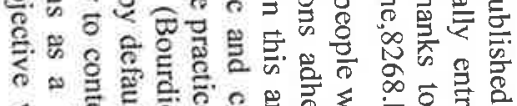

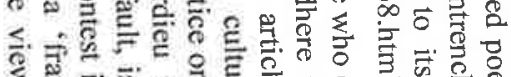

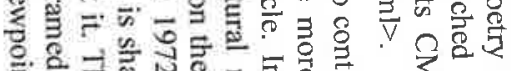

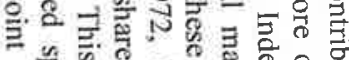

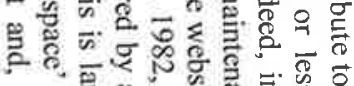

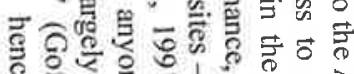
हิ 융

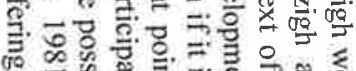

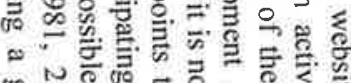

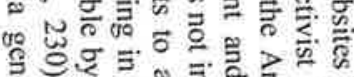

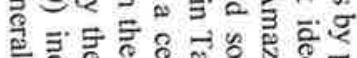

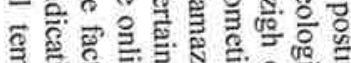

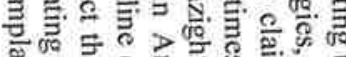
है क ज ₹ 丞题引

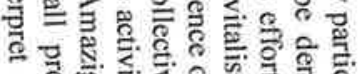

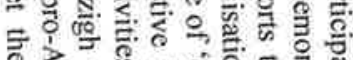
๘引

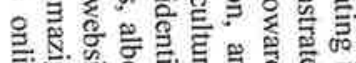

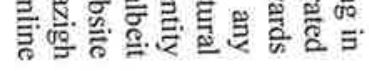

정

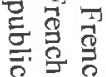

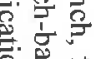
要

응 ह 38

ํํำ 宅产起 के (1) 즐

$\triangle$ है क्ष

要 密

豈号

$\sum \overrightarrow{0}$

产车

震它

ब용

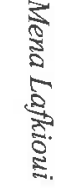

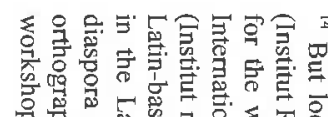

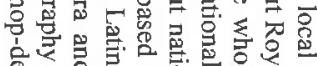

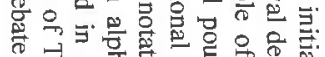

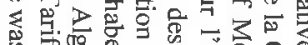

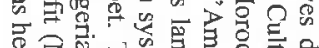

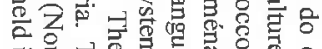

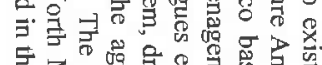

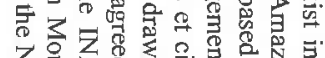

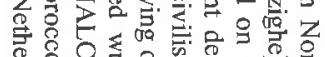

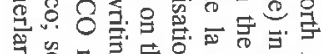

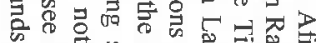

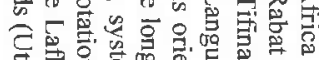

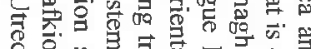

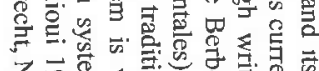

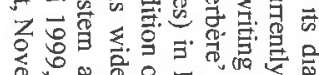

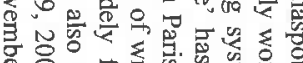

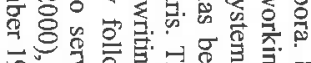

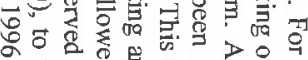

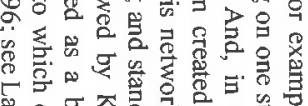

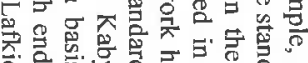

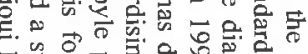

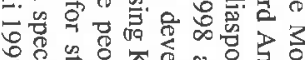

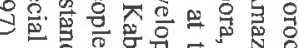

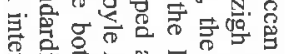

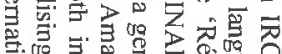

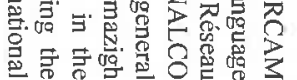

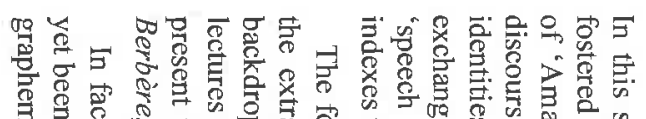

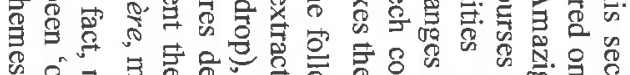

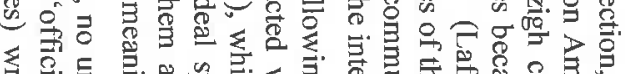

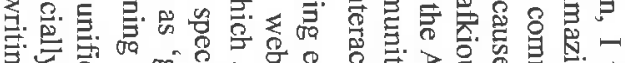
吉运串

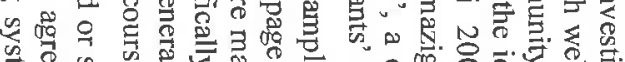

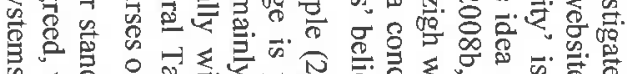

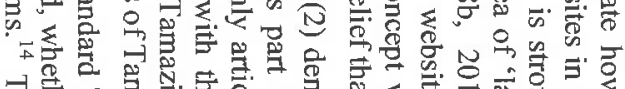

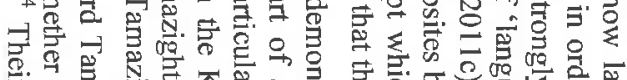

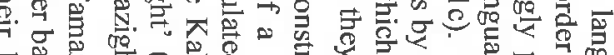

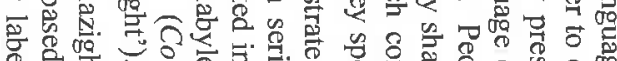

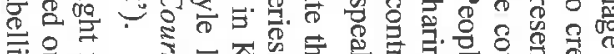

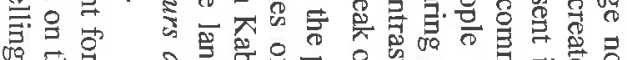

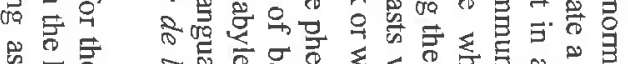

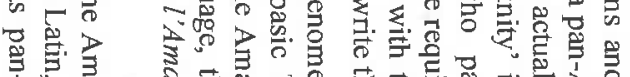

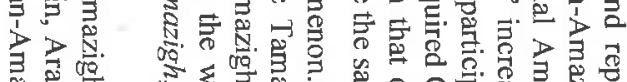

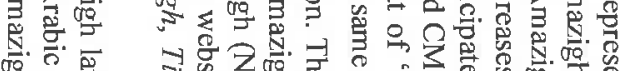

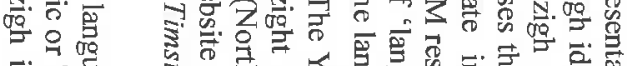

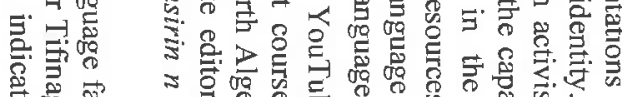

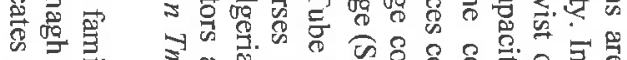

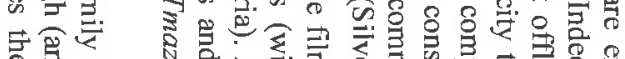

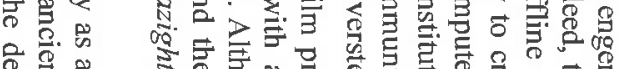

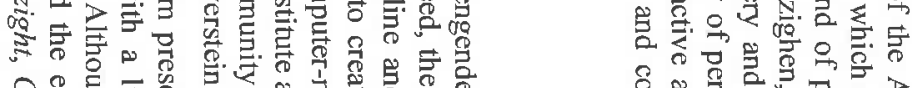

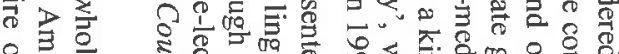

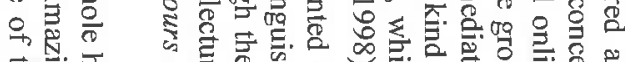

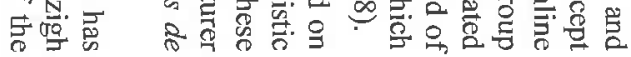
을⿺辶大

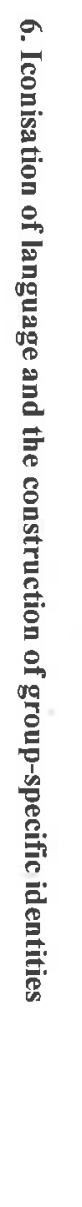

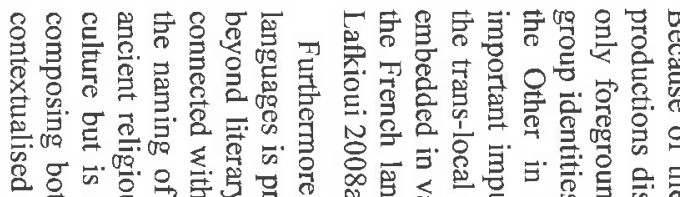

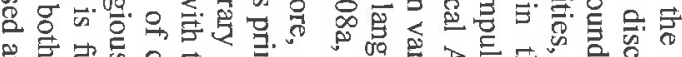

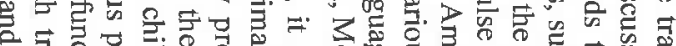

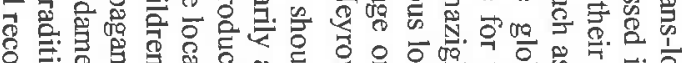

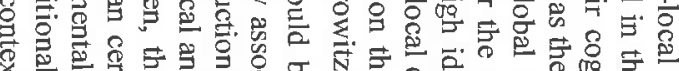

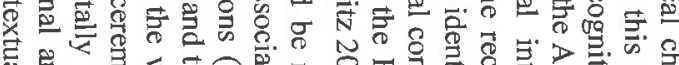

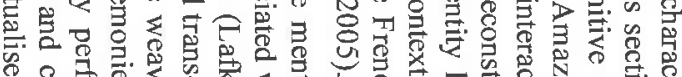

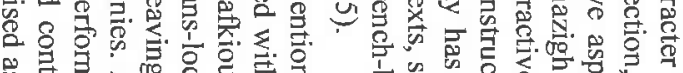

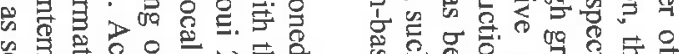

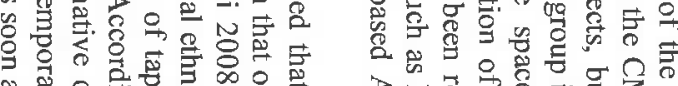

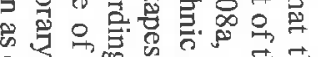

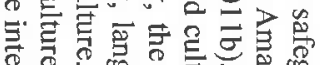

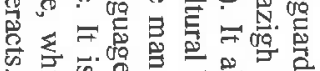

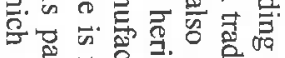

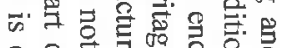

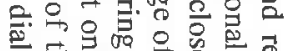

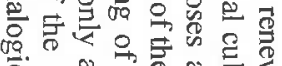
ङ

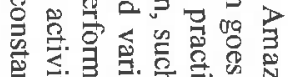

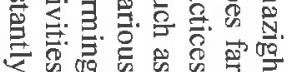

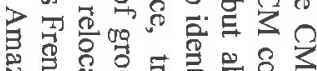

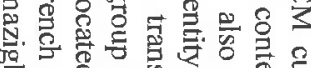

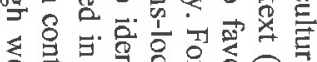

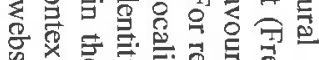

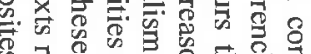

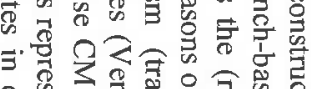

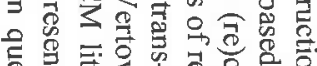

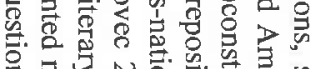
灵它

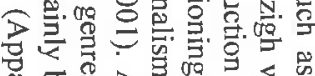

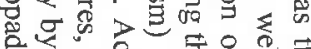

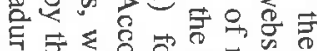

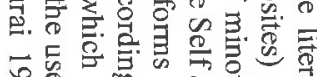

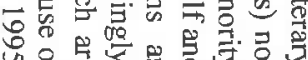




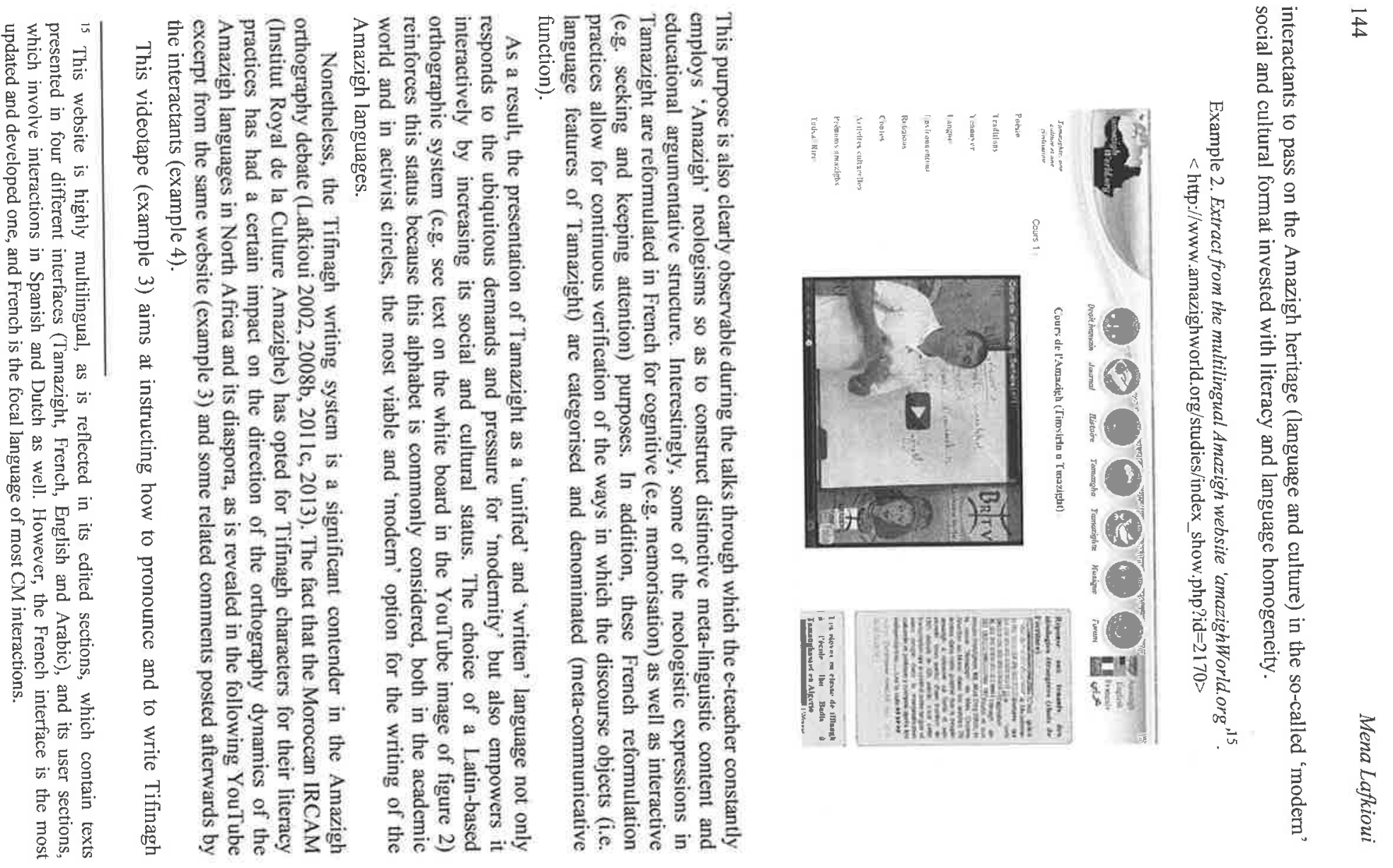

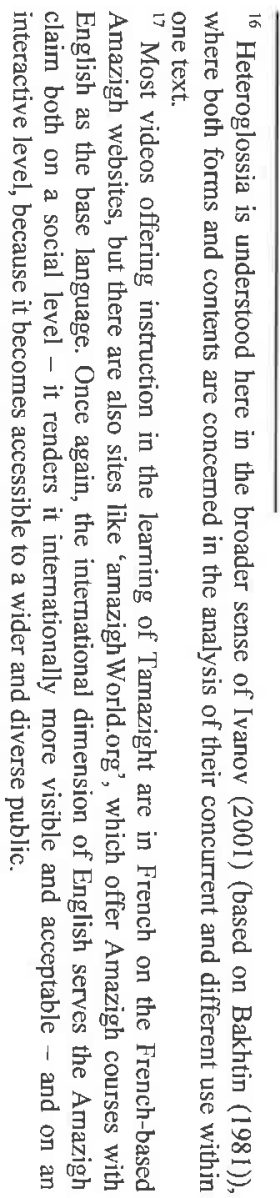
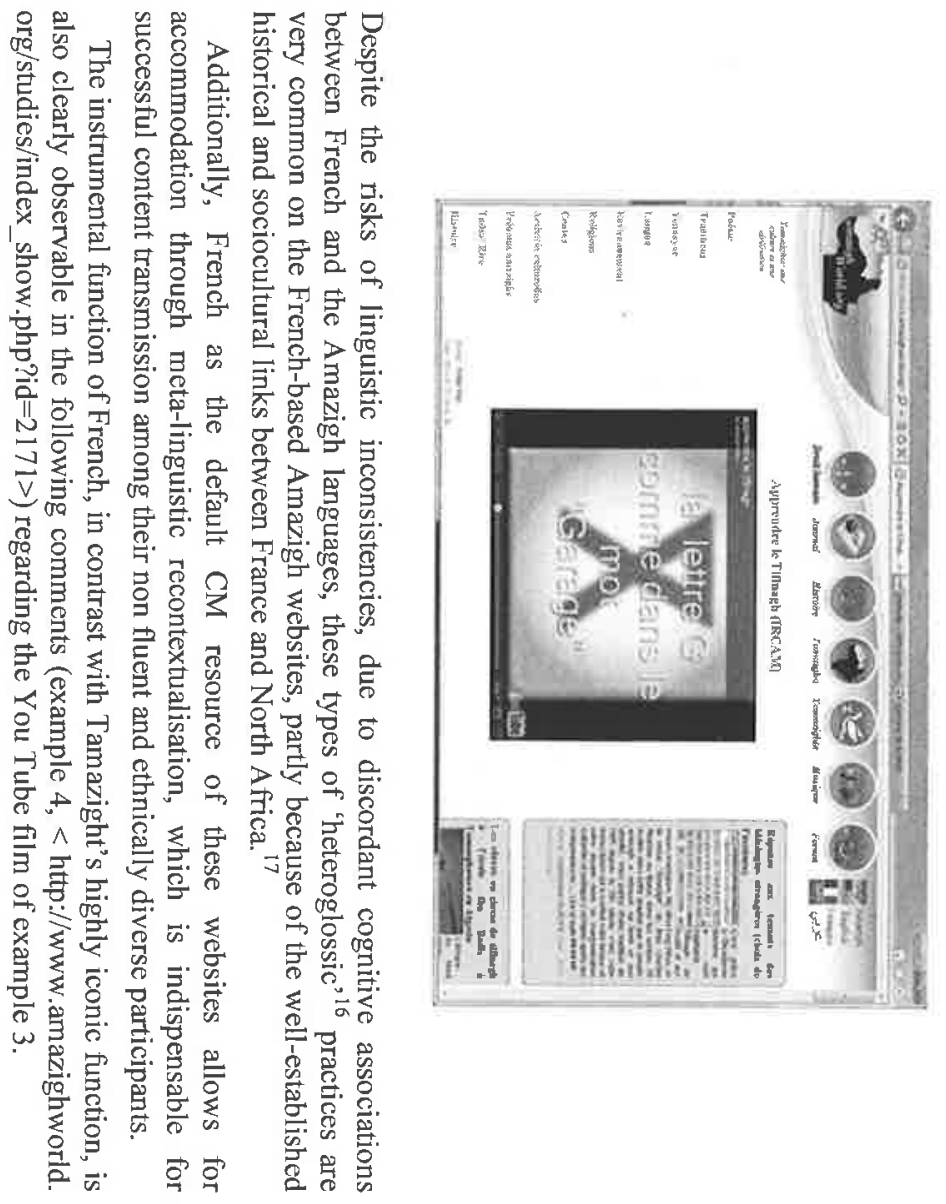

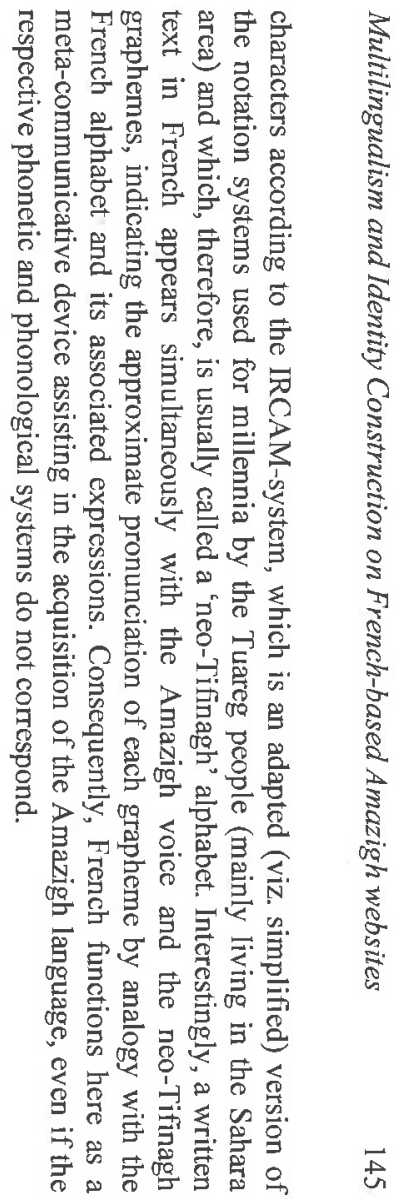




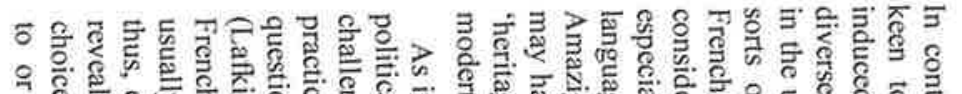

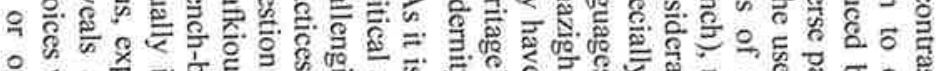

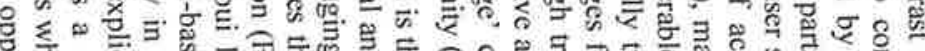

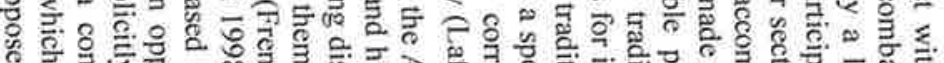

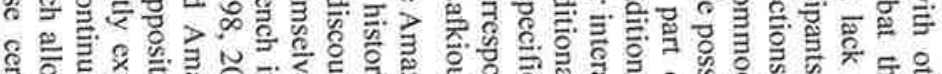
@

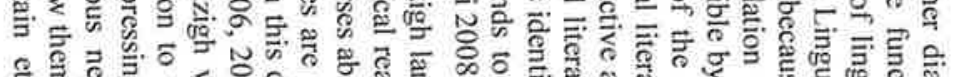

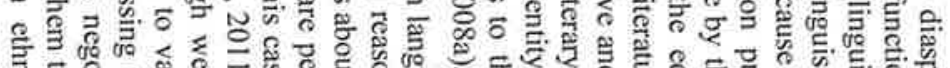
ก. o

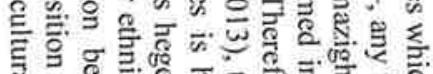

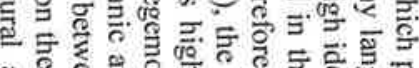

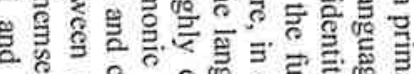

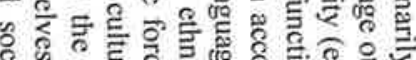

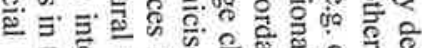

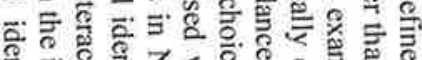

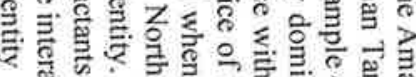

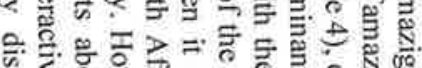

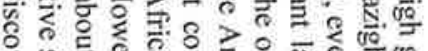

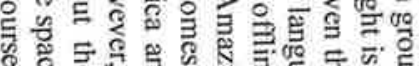

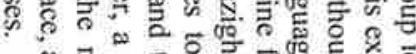

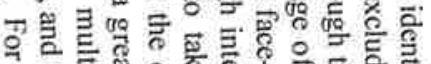

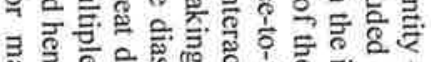

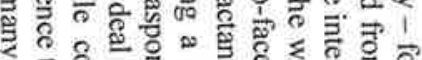
5 \&

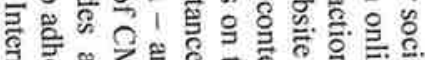

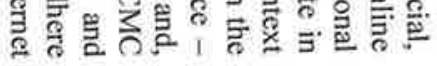

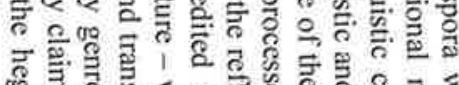

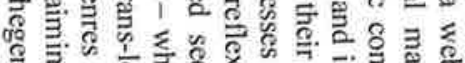

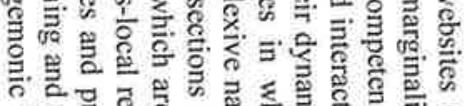

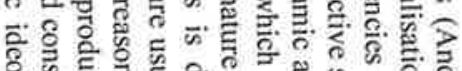

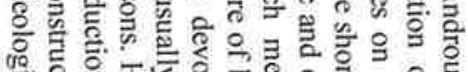

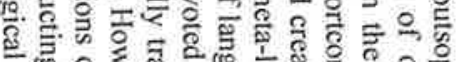

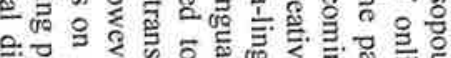

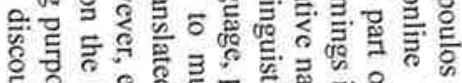

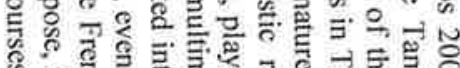

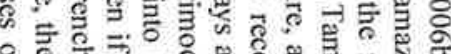

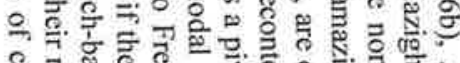

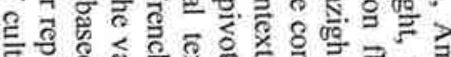

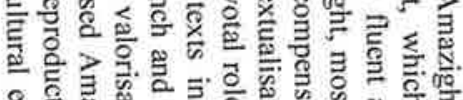

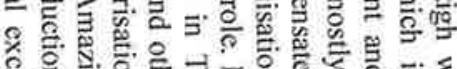

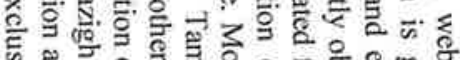
㨁

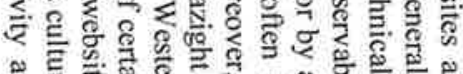

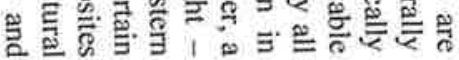

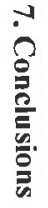

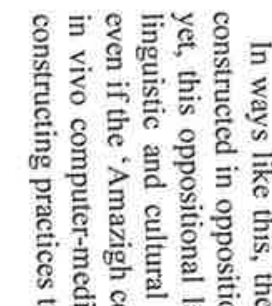
ठ융 ङ

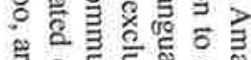
훌. 产官 के

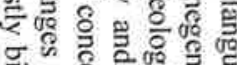

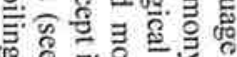

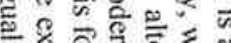

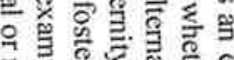

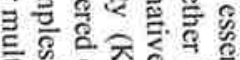
产范

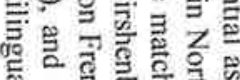

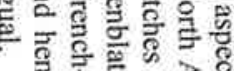
हैं 5. 造高》 . $引 \stackrel{9}{\rightrightarrows} \cong$.

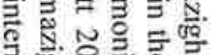
哭然 है ङ ㄱ. 象

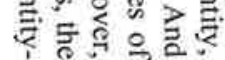

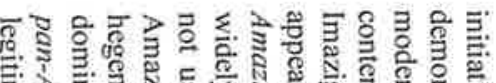

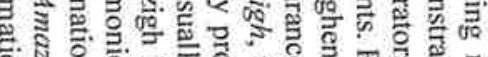
然

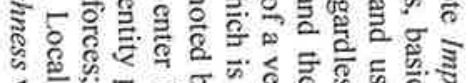
؛

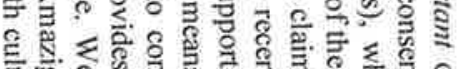

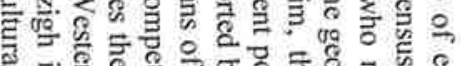

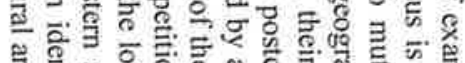

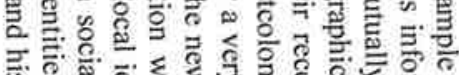

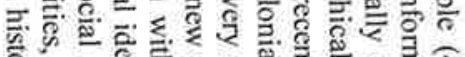

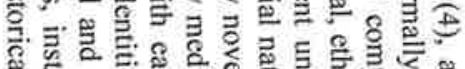
듕ํㅇ

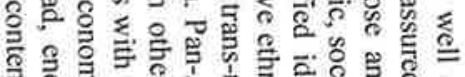

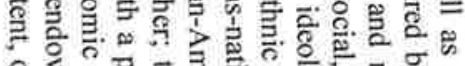

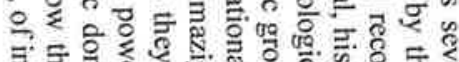

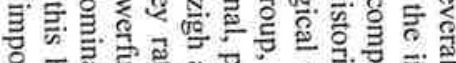

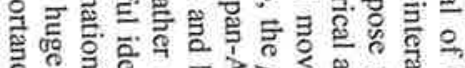

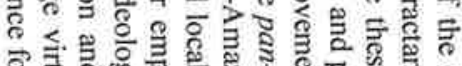

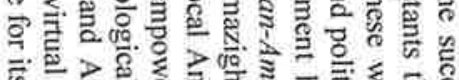

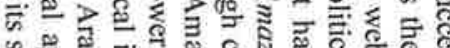

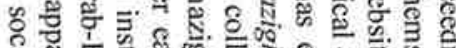

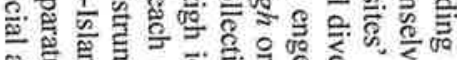

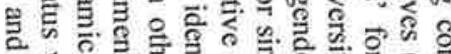

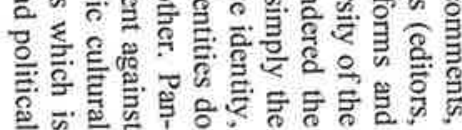

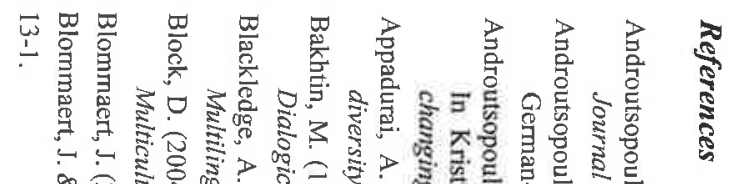

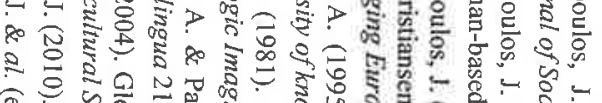

(ํ)

总

空

웅. 욱

.

空

贾

을.

票

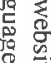

趂

คे

空.

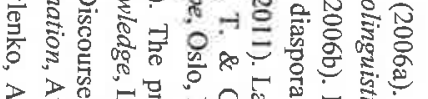

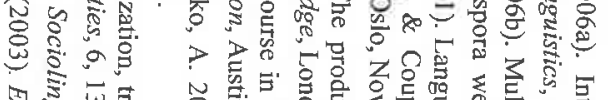

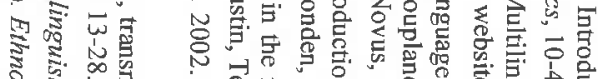

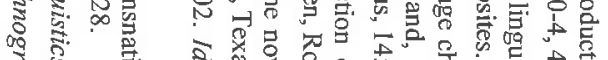

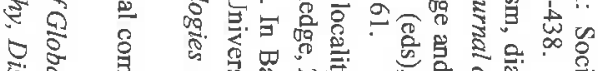

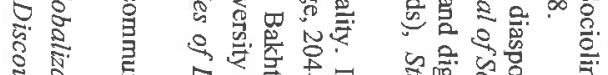

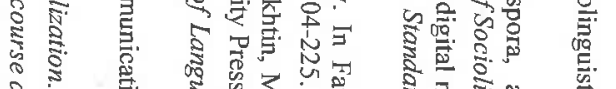

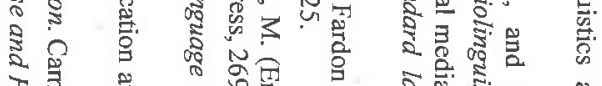

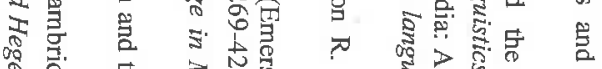

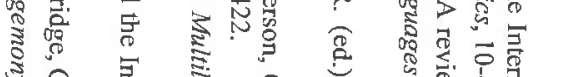

खी

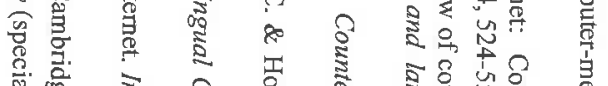

ए. "वि

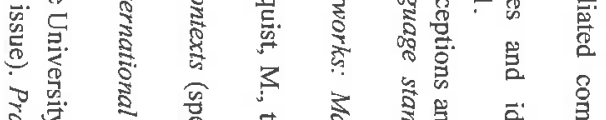

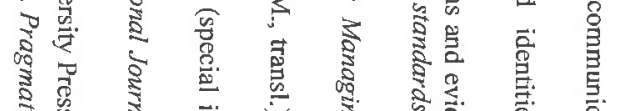

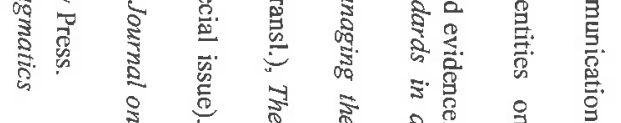

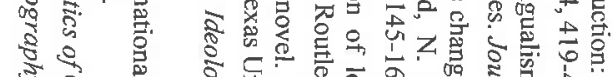

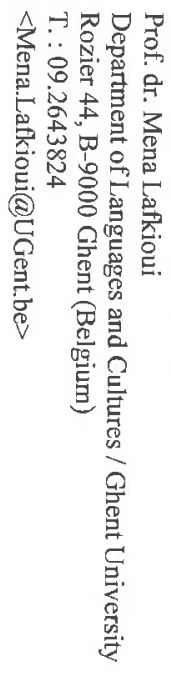

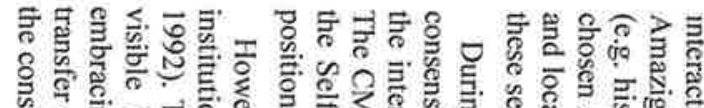

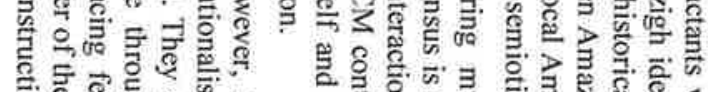

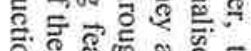

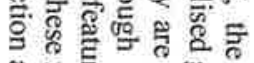

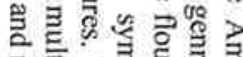

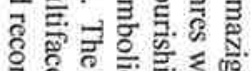

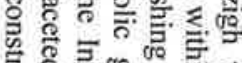

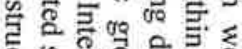

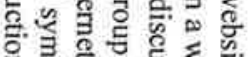

员 के

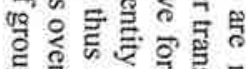

동

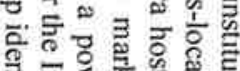

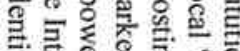

क.

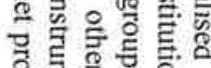

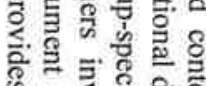

क ₹

랄 $\frac{\omega}{2}$ क

व वे के क्षे

แ

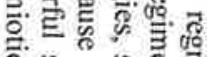

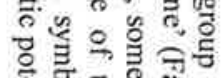

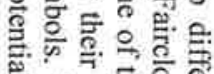

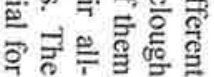

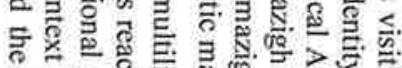

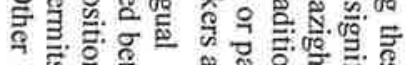
1 के है क के

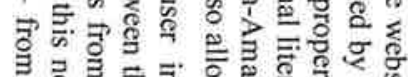
ڤ

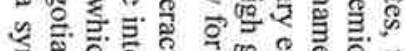

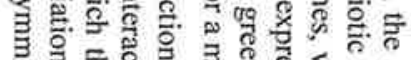

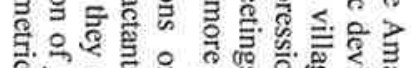

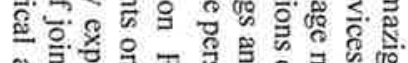

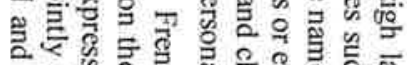

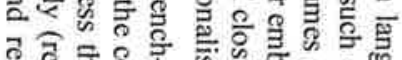
范

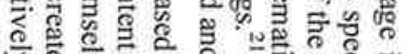

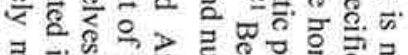

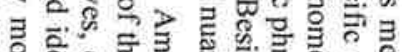

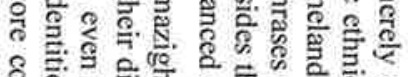
色

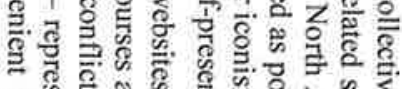

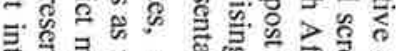

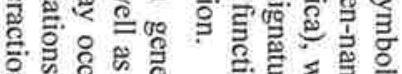

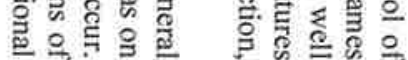

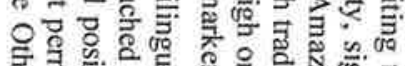

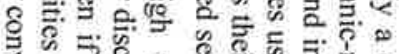

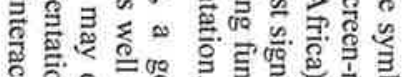




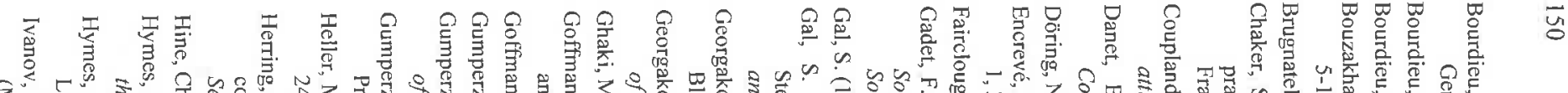

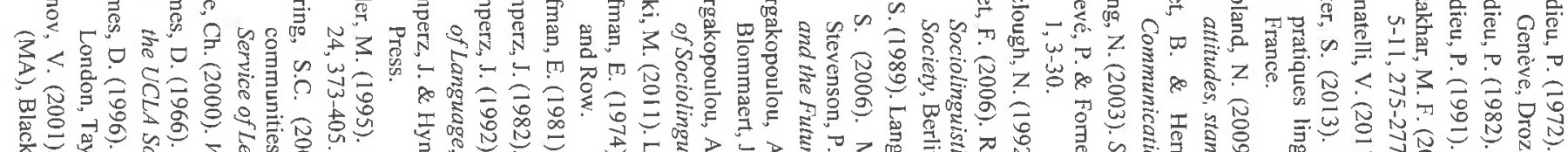

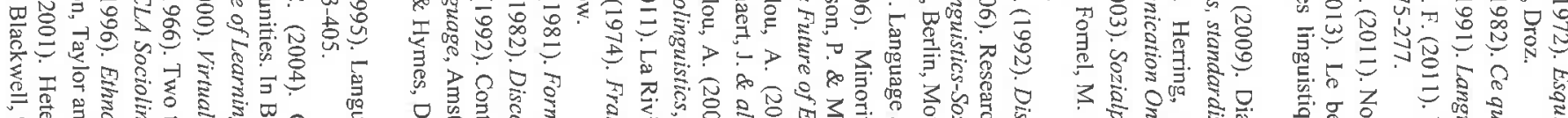

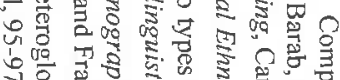

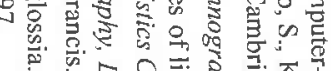

3
3

焉

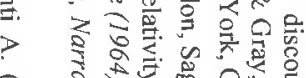

क्ष

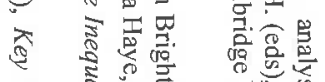

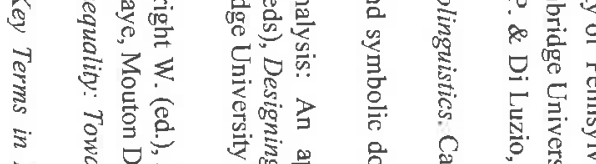

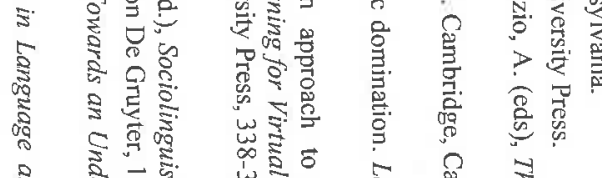

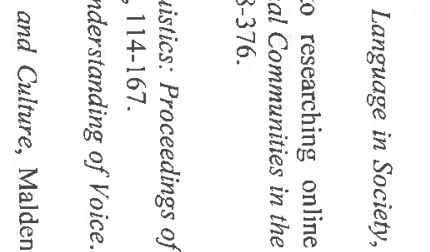

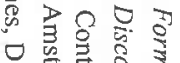

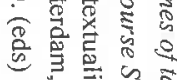

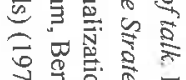

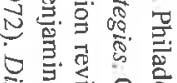

要

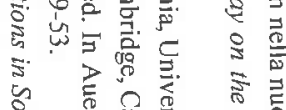

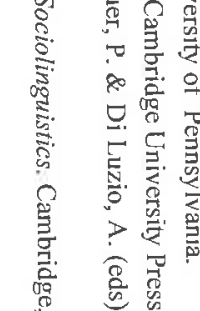

.

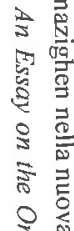

离

की

空

喜

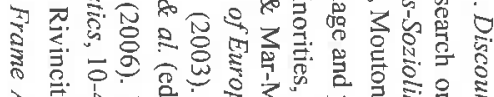

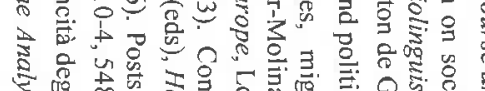

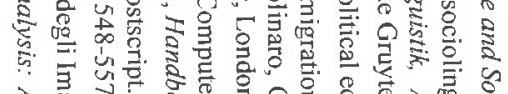

है

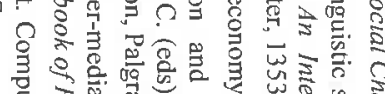

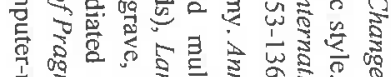

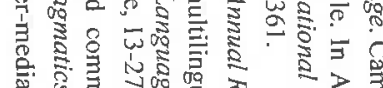

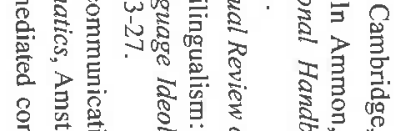

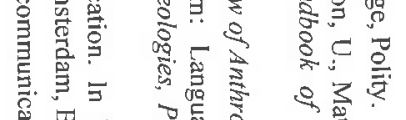

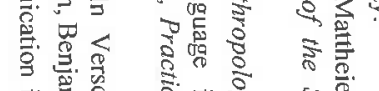

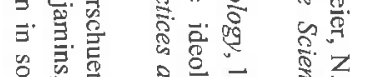

年

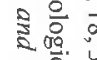

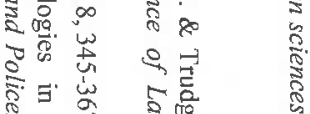

总高

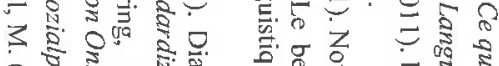

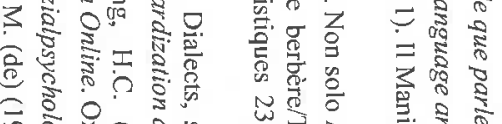

0
0
0
0
0

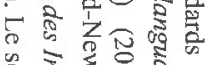

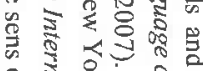

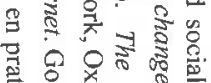

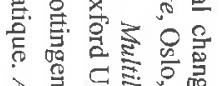

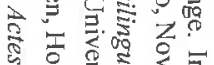

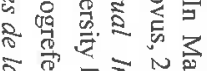

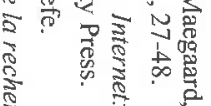

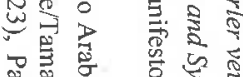

就.

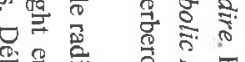

\% 을

)

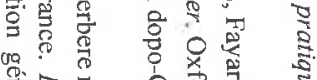

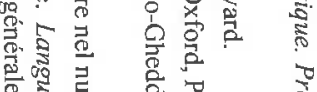

해용

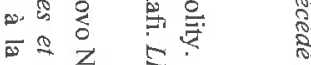

远

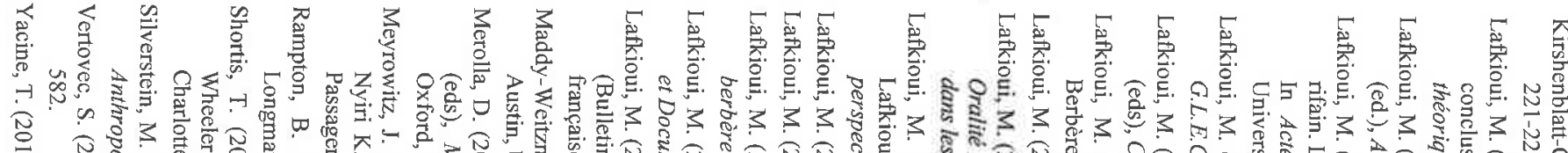

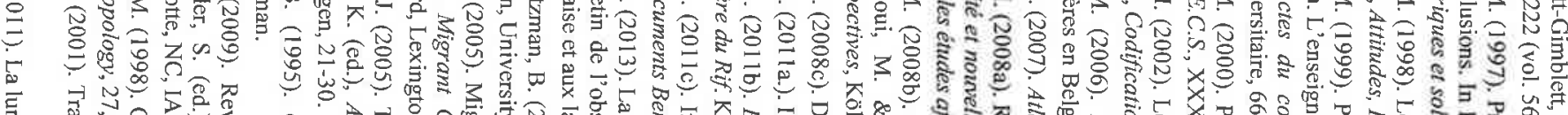

可

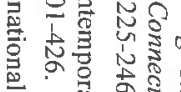

$$
1
$$

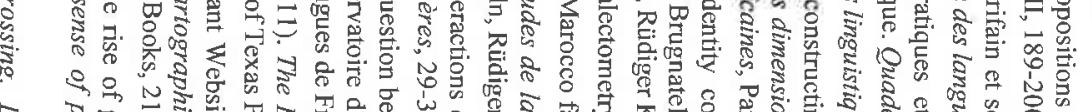

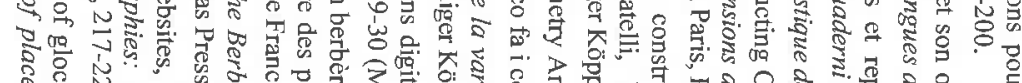

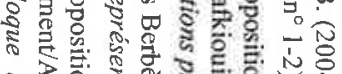

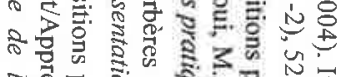

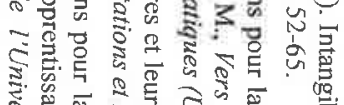

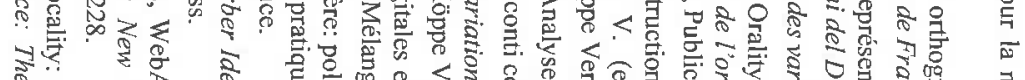

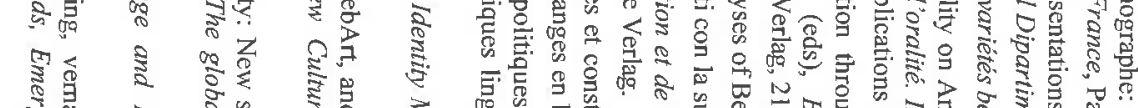

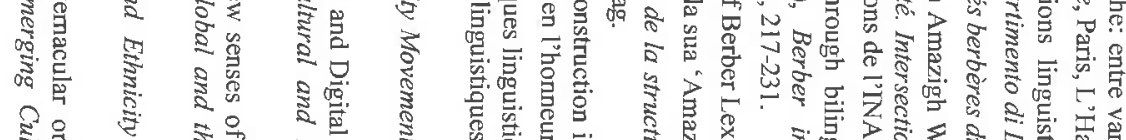

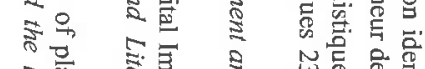

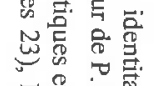

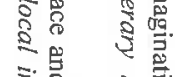

웜

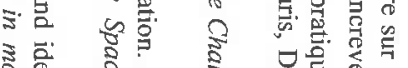

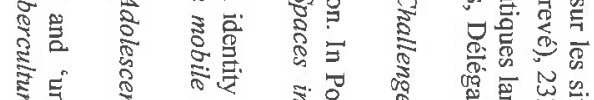

है

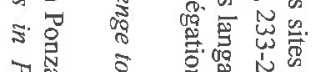

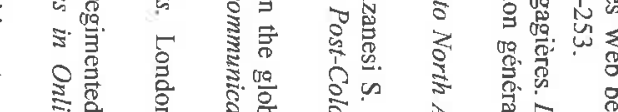

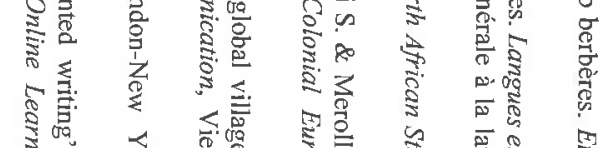

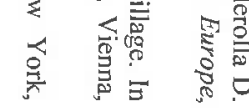
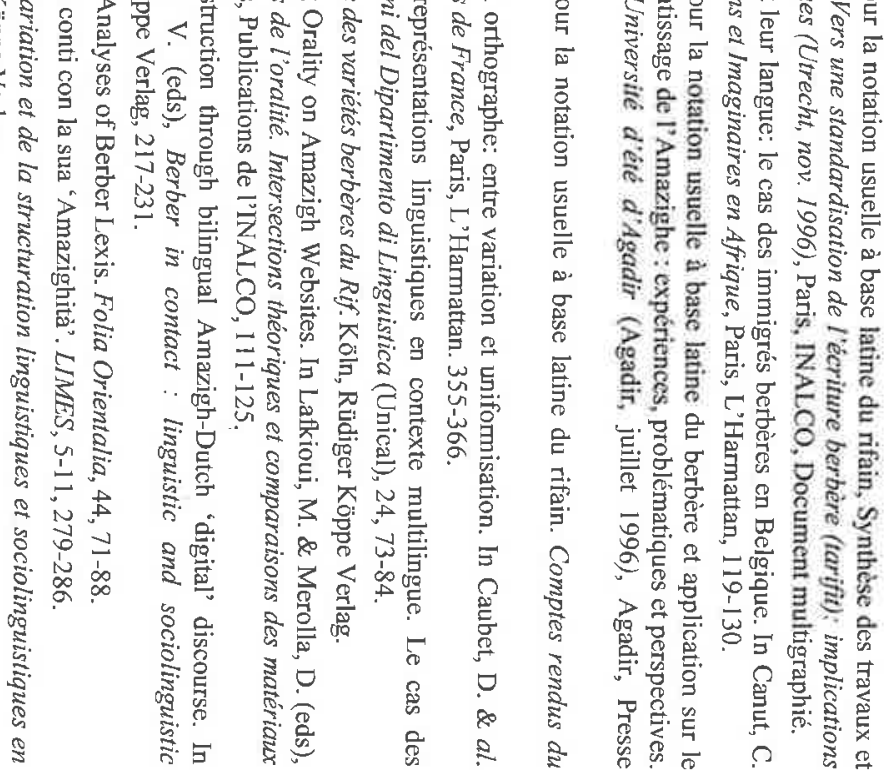

| 